\title{
RISK EDUCATION IN SERBIA
}

Jelena Kovačević - Majkić, Marko V. Milošević, Milena Panić, Dragana Miljanović, Jelena Ćalić

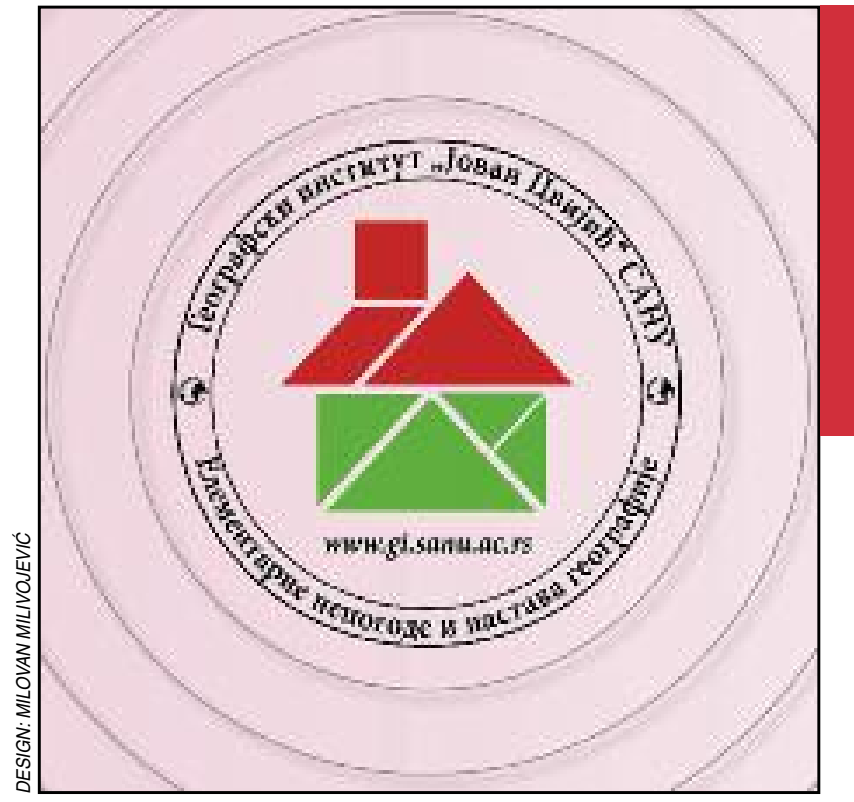

Logo of the training program for geography teachers »Natural disasters and geography teaching «, one of the rare official activities related to systematic risk education in Serbia. 


\section{Risk education in Serbia}

DOI: http://dx.doi.org/10.3986/AGS54305

UDC: $91: 504.4(497.11)$

504.4:37(497.11)

COBISS: 1.01

ABSTRACT: Natural disaster risk reduction can be achieved through vulnerability reduction, as well as through strengthening the resilience of the population. One of the segments leading to these aims is a proper risk education. It is the public (compulsory) education system that reaches the greatest number of participants and represents a good platform for the natural disaster knowledge transfer. Geography, as a complex subject that includes both natural and social components, is the most appropriate to transfer the knowledge necessary to improve the resilience. Research done in Serbia (detailed analyses of curricula, textbooks, teachers' role and pupils' knowledge) shows that children do learn about natural disasters but not in a way which provides usable knowledge.

KEY WORDS: natural disasters, prevention, education system, geography teaching, knowledge transfer, Serbia

The article was submitted for publication on August 31, 2012.

ADDRESSES:

Jelena Kovačević - Majkić, M. Sc.

Geographical Institute »Jovan Cvijić«

of the Serbian Academy of Sciences and Arts

Djure Jakšića 9, SRB - 11000 Belgrade, Serbia

E-mail: j.kovacevic@gi.sanu.ac.rs

Marko V. Milošević, M.Sc.

Geographical Institute »Jovan Cvijić»

of the Serbian Academy of Sciences and Arts

Djure Jakšića 9, SRB - 11000 Belgrade, Serbia

E-mail:m.milosevic@gi.sanu.ac.rs

Milena Panić, M. Sc.

Geographical Institute »Jovan Cvijić«

of the Serbian Academy of Sciences and Arts

Djure Jakšića 9, SRB - 11000 Belgrade, Serbia

E-mail:m.panic@gi.sanu.ac.rs

Dragana Miljanović, M. Sc.

Geographical Institute »Jovan Cvijić"

of the Serbian Academy of Sciences and Arts

Djure Jakšića 9, SRB - 11000 Belgrade, Serbia

E-mail: d.miljanovic@gi.sanu.ac.rs

Jelena Ćalić, Ph. D.

Geographical Institute »Jovan Cvijić«

of the Serbian Academy of Sciences and Arts

Djure Jakšića 9, SRB - 11000 Belgrade, Serbia

E-mail: j.calic@gi.sanu.ac.rs 


\section{Introduction}

According to the majority of relevant references related to the issue of natural disaster risk reduction, various forms of education play an extensive role in this process (e.g. Agenda 21, Hyogo Framework for Action 2005-2015, UN Decade of Education for Sustainable Development 2005-2014, the UN campaigns »Disaster Reduction, Education and Youth « 2000 and »Disaster Risk Reduction Begins at School " 2006-2007, etc.). Education contributes to the realistic risk perceptions, to raising awareness of the possible outcomes, as well as to gaining the necessary knowledge about the proper protective behaviour. It is a platform for building a culture of prevention and disaster-resilient societies. According to Singh (2007), the final outcome of education is "... to enable individuals to become proficient as citizens, having knowledge to make informed decisions that will either help them avoid hazardous situations or enable them to mitigate the effects of a natural disaster ..." (Singh 2007, 416). Zorn and $\operatorname{Komac}(2011,8)$ state that prevention is »... key activity in the field of protection against natural disasters. «. Smaller number of casualties and reduced material damage are a proven outcome of prepared and educated societies (Izadkhah and Hosseini 2005). Education about natural disasters leads to risk reduction and fits to the Pressure-and-Release model defined by Wisner et al. (2004). Out of 8 types of vulnerability defined by Aysan (1993, cited in Alcántara-Ayala 2002), three may be substantially reduced through education: educational vulnerability (lack of access to information and knowledge), attitudinal and motivational vulnerability (lack of public awareness), and cultural vulnerability (related to beliefs and customs). Kuhlicke et al. $(2011,810)$ define the risk education as a »...purposeful transfer of more generalised (thematic, organisational or technical) knowledge on hazards and risks from professionals in teaching institutions to usually (but not necessarily) younger persons within a formalised setting...«.

The aim of this paper is to present a detailed analysis of the present level of education related to hazards and risk in Serbia. The initial research included the analysis of legislation, school curricula and geography textbooks. In the next steps, the research was extended in the direction of practical aspects - geography teachers' attitudes about inclusion of disaster issues in teaching, as well as evaluation of the present level of knowledge and preparedness of the pupils who experienced a relatively strong earthquake. A particular challenge of the whole research was the fact that the risk education is not included in the formal geography curriculum, so the participants in the process (experts, teachers) are about to find the alternative solutions to start the pioneer work in this field in Serbia.

\section{Theoretical background}

In the further text, we use the term »natural disaster « according to the explanation given by the UNISDR $(2009,09)$, which describes the notion of a natural disaster as a »... result of the combination of: the exposure to a hazard; the conditions of vulnerability that are present; and insufficient capacity or measures to reduce or cope with the potential negative consequences...".

\subsection{Why children?}

There are three main reasons why the children are in the limelight when it comes to hazard and risk education. The first, as stated by UNISDR (2007) and Ronan et al. (2012), is that the children are the most vulnerable part of a population in case of natural disasters. The second reason, as opposed to the first, is the fact that the children are most liable to change their views and behaviour patterns (Fridl et al. 2009) and at the same time possess considerable strengths, as stated by Peek (2008). The same author reminds that the children's creativity, energy, enthusiasm, and social networks are valuable in the process of risk reduction (Peek 2008), in which children can play an active part (UNISDR 2007). They are now not regarded merely as potential victims, but as catalysts for loss reduction (Clerveaux and Spence 2009). The third reason, considered in a longer time span, is that the children are regarded as "tomorrow's leaders « and »key agents for change (UNICEF and UNISDR 2011), as well as the "powerful forces in behavioural change for the next generation« (Izadkhah and Hosseini 2005). 


\subsection{Why formal (compulsory) education?}

In numerous studies and articles formal education is stressed because of its important role in learning on natural disasters (e.g. Wisner 2006; Fridl et al. 2009; Komac et al. 2010; Komac et al. 2011). Without diminishing the importance of informal learning, we insist on the role of formal and compulsory education, considering the fact that the majority of the population acquire this type of education. The effectiveness of school-based hazard education programs is claimed by many authors (e.g. Ronan et al. 2010; Gulay 2010; Finnis et al. 2010; Johnston et al. 2011).

Kuhlicke et al. (2011) highly recommended a combination of a) curriculum based, standardized education and b) participatory, locally embedded education, which correspond to formal and informal education. Although this is an ideal option, in reality it is sometimes difficult to organize the parallel implementation of both types. In case when the capacities are insufficient to provide the combination of two types of education, it is more efficient to opt for the first type, because the effective risk reduction requires a large proportion of the population who receives the best training possible, while informal education affect small parts of population.

\subsection{Why geography?}

Geographical knowledge, by joining and overlapping of physical (natural) and human (social) elements, is often regarded as a knowledge "for living ", having daily and vocational applications (Gritzner 2004), one of which is certainly the role in prevention of natural disasters. For the same reasons, according to Mitchell (2009), geography is the natural academic »home« for teaching about hazards. As the risk reduction certainly includes the Human-environment relations (HER), the necessary integrative approach is provided through geography as a science (Golledge 2002). Therefore, the position within the risk research is one of geography's greatest strengths (Cross 2009; Stoltman 2006). The same may be applied when discussing the position of geography as a subject in the system of formal (compulsory) education. The above mentioned references prove that geography is the adequate solution for the inclusion of risk education into the education system.

In Serbia, according to official statistics, about 70,000 pupils enroll each year in the $1^{\text {st }}$ grade of primary school, which is compulsory and lasts for eight years (Statistical Survey of Serbia, 2012). Through eight years of primary education, risk education may be gradually included, in accordance with the age, through the subjects »Nature and Society«, »The World Around Us « $\left(1^{\text {st }}\right.$ to $4^{\text {th }}$ grade $)$ and especially »Geography« $\left(5^{\text {th }}\right.$ to $8^{\text {th }}$ grade) (Figure 1$)$.

Secondary education is not compulsory, but it is anyway enrolled by about 70,000 students each year (the majority of them finish this level). However, due to its shorter duration and different programs, it cannot be equally efficient in risk education.

A small number of the population enrolls higher education (university level) and informal types of education. Although some faculties do cover some natural disaster issues in relatively small parts of their curricula, this level of education has a lesser importance in the overall system of natural disasters prevention, due to small coverage. One of the examples in which this small part of population (studying natural disasters at the university level) may be valuable to the system of risk education is, for the beginning, to clear the terminological inconsistencies in the field of natural disasters. Even in expert circles (presentations, articles, and other literature) it often happens that the terminology is used incorrectly and randomly, which reduces the proper wider understanding of processes and interactions. For example, the term »risk " is generally overused, and in majority of cases its use actually refers only to hazard (i.e. does not include vulnerability and resilience).

\section{Methods used}

The actual situation in risk education in Serbia is analyzed at several levels:

- analysis of the official legislation structure related to the issue of risk education;

- analysis of geography textbooks for primary and secondary schools;

- analysis of geography teachers' opinions on the subject; and

- analysis of children's reactions, knowledge and attitude after a particular disaster event (M 5.4 earthquake in the town of Kraljevo). 


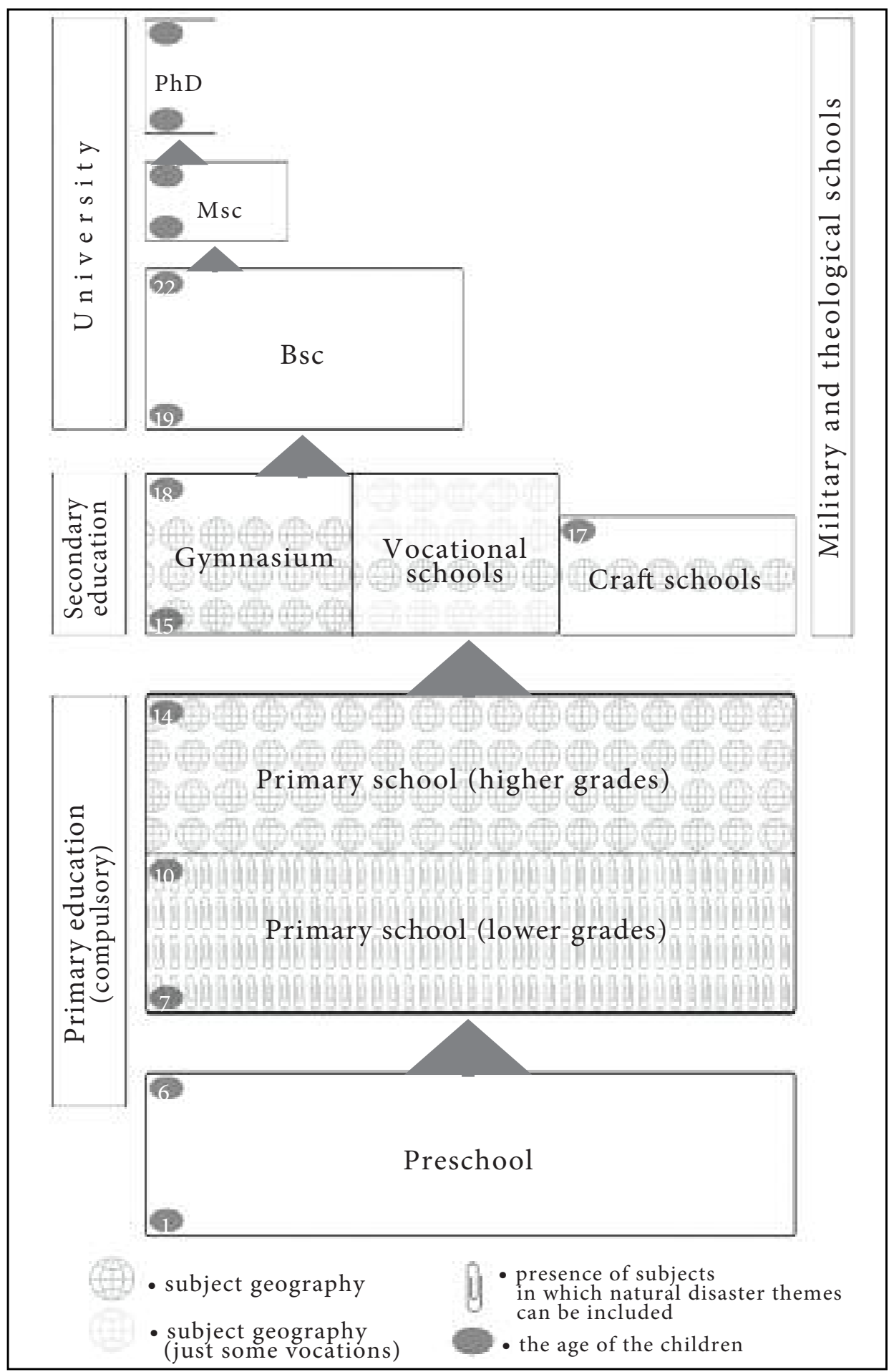

Figure 1: Educational system in Serbia. 
Legislation structure analysis is related particularly to legislation within the Serbian educational system, which directly or indirectly regulates teaching about natural disasters. It includes laws, by-laws, strategies, regulations (rule books), but also the international conventions, which, after a ratification, automatically became parts of Serbian internal legislation.

The analysis of geography textbooks for primary and secondary schools was done on a qualitative basis, and included not only the texts, but also the illustrations (charts, sketches, photographs) and thematic maps.

The evaluation was done following the three main principles: perception principle, spatial principle and temporal principle.

- The perception principle considers various qualifications on particular natural processes, depending on textbook authors and their experiences. It is analyzed whether the particular processes are treated only as natural processes of increased intensity or, on the other hand, they are treated as a natural disaster (as defined in the chapter Theoretical background of this paper). If an event is treated only through its genesis and its influences on spatial physiognomy, it has a category of a hazard - a natural process of increased intensity. In cases where an event is treated through its impact on society and its transformation, it has a category of a natural disaster. There is also a third case - when the authors point to some positive impacts of natural processes of increased intensity.

- The spatial principle stands for the analysis of spatial distribution of natural hazards and disasters studied in textbooks (reactions of children are different for the events in Serbia than for the events abroad).

- The temporal principle stands for the analysis of time span between a disaster occurrence and the time when the information about it appears in the textbooks.

Analysis of teachers' opinions regarding teaching on natural disasters was done with participation of 361 teachers who attended a specialized training program »Natural disasters and geography teaching«. The research included two steps. The first step was a poll survey using a short questionnaire aimed at establishing whether the teachers are in a position to actually transfer the knowledge they gained at the training program. The close-ended question »Is this program applicable in practice, in schools? « was chosen to determine whether they can include this issue in their classes, regardless of the fact that it is actually not a part of the official curriculum. The offered answers were scaled in 5 options (ordinal-polytomous items), ranging from »I completely agree « to »I completely disagree«. The second phase was an interview aimed at detection of the reasons for the negative answers they gave in the questionnaire.

The analysis of children's behaviors, feelings and knowledge in case of a natural disaster, their knowledge about natural disaster threats in their living area, and sources of that knowledge, was done through a poll survey in the town of Kraljevo. Kraljevo faced a M 5.4 earthquake on November $3^{\text {rd }} 2010$ at 1:56 AM and suffered relatively large material damage, with two victims. The poll survey was carried out within a time distance of 16 months after the event. The research included a sample of 300 children: 153 primary school pupils from $5^{\text {th }}$ to $8^{\text {th }}$ grade (aged 11-15) and 147 secondary school students from $1^{\text {st }}$ to $4^{\text {th }}$ grade (aged 15-18). Among the primary school pupils there were more boys (52\%), while in secondary schools the number of girls prevailed $(60 \%)$. All participants have a permanent residence in the town of Kraljevo, 56\% of whom live in individual residential facilities. The questionnaire consisted of 17 close-ended questions, five of which were selected for this particular research (activities and feelings during the earthquake, awareness about the seismic hazard in the area, sources of knowledge about earthquakes, and the type of future training they need). The response scales were nominal-polytomous or dichotomous. The results were processed using the SPSS software. The tests applied include descriptive statistics and non-parametric tests (Pearson chi-square test, binomial test).

\section{Results}

\subsection{Legislation analysis}

In the Republic of Serbia, the legislation related to risk education is defined by particular education laws, as well as by other laws which do not directly refer to education but mention the education issues in other contexts. Enacting of laws related directly or indirectly to risk education is under the jurisdiction of two ministries: Ministry of Education and Science and Ministry of Interior Affairs. Intersectoral collaboration in treating of these issues is generally not synchronized, which results in the lack of desired effects 
of enacted laws. In other words, up to now, the framework laws have not yet led to enacting of new proficient by-laws in the field of education.

Legislation on risk education in Serbia is composed of the following elements (figure 2):

International conventions: The Hyogo Framework for Action 2005-2015 has been one of the bases for enacting of the Law on Emergency Situations and the National Strategy on Protection and Rescue in Emergency Situations.

Particular laws on education and emergency situations are listed in Tab. 1. The Article 119 of the Law on Emergency Situations foresees that training is done through primary and secondary education, for getting knowledge on the dangers of natural and other disasters, as well as for protection.

The Article 4 Paragraph 5 of the Law on the basics of education system states that one of the general aims of the education process is to make children »capable of solving the problems, application of knowledge and skills in further education, professional work and everyday life«, which completely corresponds to the need for risk education.

The Laws on primary and secondary schools (Articles 20 and 24, respectively), declare that the curriculum is enacted by the Minister of education, according to the suggestion of the advisers for particular subjects.

Table 1: Laws in the Republic of Serbia related to education and risk management

\begin{tabular}{ll}
\hline Law & Official gazette number \\
\hline Law on Emergency Situations & $111 / 09$ \\
Law on the Basics of Education System & $72 / 2009,52 / 2011$ \\
Law on Primary Schools & $50 / 92,53 / 93,67 / 93,48 / 94,66 / 94,22 / 02,62 / 03,64 / 03,101 / 05,72 / 09$ \\
Law on Secondary Schools & $50 / 92,53 / 93,67 / 93,48 / 94,24 / 96,23 / 02,25 / 02,62 / 03,64 / 03,101 / 05,72 / 09$ \\
\hline
\end{tabular}

Strategies: The National Strategy on Protection and Rescue in Emergency Situations (2011) says within the Strategic section 3 that »issues related to protection, rescue and disaster risk reduction should be incorporated into the curricula of all educational institutions".

Curricula are defined in the Regulations enacted by the Ministry of Education (table 2). The analyzed regulations for the primary school curricula show that there is only one lesson related to some kind of natural disasters: "Volcanism and earthquakes « in the $5^{\text {th }}$ grade. There are two kinds of secondary schools, with different curricula: gymnasium and vocational schools. In the $1^{\text {st }}$ grade of gymnasium, there are three lessons partially related to natural disasters: Volcanism; Earthquakes (with seismically active zones in Serbia); and Precipitation. In other gymnasium grades there are no geographical lessons treating the issue of natural disasters. Among the vocational schools, only in the $2^{\text {nd }}$ grade of touristic vocational school, there are two geography lessons related to natural disasters: Water-management problems in Serbia; and Natural disasters. The fact that Curricula are a bottleneck not properly transferring the legislation-provided possibilities towards the schools is one of the important conclusions we have reached in this study.

Table 2: Regulations on the school curricula in the Republic of Serbia

Regulations

Službeni glasnik (Official gazette - Educational gazette) number

Regulation on the Plan for the $2^{\text {nd }}$ cycle of primary education

and the Curriculum for $5^{\text {th }}$ grade of primary education

$6 / 2007,2 / 2010,7 / 2010,3 / 2011$

Regulations on the Curricula for $6^{\text {th }}, 7^{\text {th }}$ and $8^{\text {th }}$ grade

of primary education

$5 / 08,6 / 09,2 / 2010$

Regulation on the Plan for the gymnasium education

and the Curriculum for $1^{\text {st }}$ grade of gymnasium

$110-00-32 / 97-01$

Regulation on the Curriculum for $2^{\text {nd }}, 3^{\text {rd }}$ and $4^{\text {th }}$ grade

of gymnasium

$11 / 2006$

\subsection{Geography textbooks evaluation}

The perception principle: The above-mentioned Curricula directed the contents of geography textbooks. Within this research, 23 geography textbooks were analysed, all of which are formally approved by the Ministry 
INTERNATIONAL CONVENTIONS

\section{LAWS ON EDUCATION AND EMERGANCY SITUATIONS}

GEOGRAPHY TEACHING

Figure 2: Legal framework for the establishment of Risk education in Serbia. The Curricula are a bottleneck not properly transferring the legislation-provided possibilities towards the schools.

of Education for usage in schools. Greater variety of textbooks is characteristic for the primary school, especially $5^{\text {th }}$ grade (six different textbooks), while secondary school programs mostly have one available textbook per grade.

The lessons precisely defined by the curricula occur regularly in all textbooks, regardless of the publisher and the edition. Additional contents and aspects related to natural disasters occur randomly, depending on the authors of the textbooks. Unfortunately, the processes which are systematically studied in all textbooks are presented as hazards (natural processes) and not as natural disasters. Geography textbooks mention the following natural processes which may have the characteristic of a disaster: meteorites, earthquakes, volcanoes, tsunamis, landslides, avalanches, floods, tropical cyclones, tornadoes, hail (table 3). Only several authors mention these processes in the context of natural disasters. The example of the lesson Earthquakes $\left(5^{\text {th }}\right.$ grade) shows that its main function is to explain the functioning of plate tectonics, which is common for all $5^{\text {th }}$ grade textbooks. Only in two editions the lesson includes a short instruction on how to properly behave during an earthquake (Sitarica and Tadić 2010, Milivojević and Ćalić 2012).

In the lessons in human and regional geography, natural disasters are occasionally mentioned in a positive context. The most typical examples are the floods in the valleys of the Nile River and the Tigris-Euphrates River system, or the volcanic activity in Indonesia, which in longer time spans lead to formation of natural resources, such as high quality soils or ores (e.g. Jakovljević and Birovljev 2012; Đurić 2011) (Figure 3). The lessons on Egypt mention the Nile floods mostly as a process which enabled the formation and development of the whole country, while only few authors point also to the negative consequences of the Nile floods (Sitarica and Tadić 2010).

The spatial and temporal principles: The analysis of geography textbooks showed that the majority of the described examples of hazaZrds and disasters are situated out of Serbia - either in European or, even more often, non-European countries. The most obvious examples are earthquakes: many Serbian textbooks describe the M9.1 earthquake in the Indian Ocean in 2004, while none mentions multiple M 5 events 


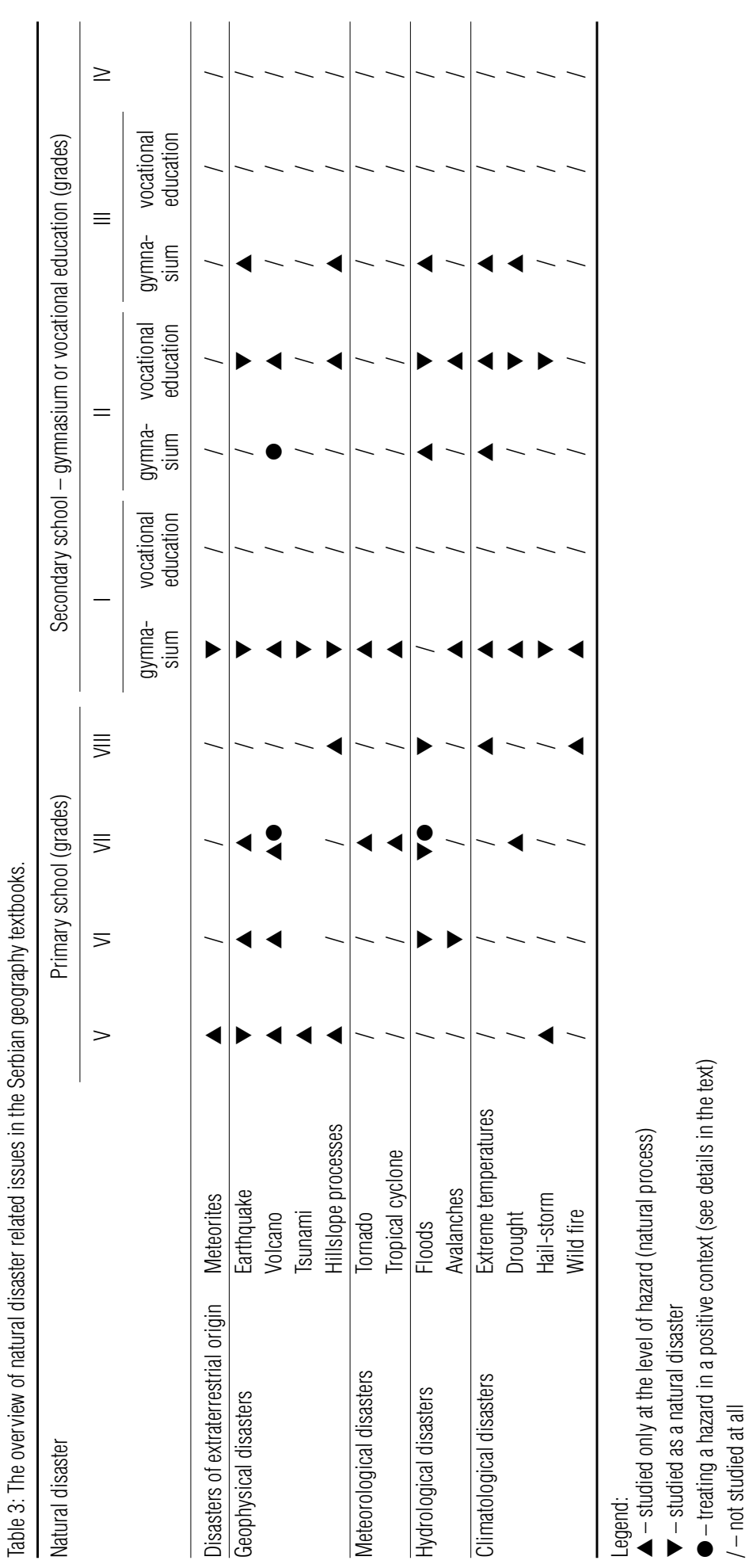


in Serbia, which in fact have much greater impact on the real everyday situations. The reason for this paradox lies within the fact that textbooks tend to show the most intensive event of a kind, and these are almost never related to Serbia. In terms of spatial aspect, in some European countries there is the opposite case, meaning that content of geography textbooks is primarily related to their own countries (Senegačnik 2010). On the other hand, in Serbia, the fact that the 2004 Indian Ocean earthquake has its place in many textbooks shows a good temporal accordance between an event and the time of textbook response.

The greatest natural disasters in Serbia in the period 2000-2011 were: the floods of the Tamiš River in 2005 , numerous landslides (e.g. Bogdanje) in the spring of 2006 , extreme air temperatures $\left(44.9^{\circ} \mathrm{C}\right.$ in Smederevska Palanka) in 2007, and the Kraljevo earthquake (M 5.4) in 2010. Although these disasters of

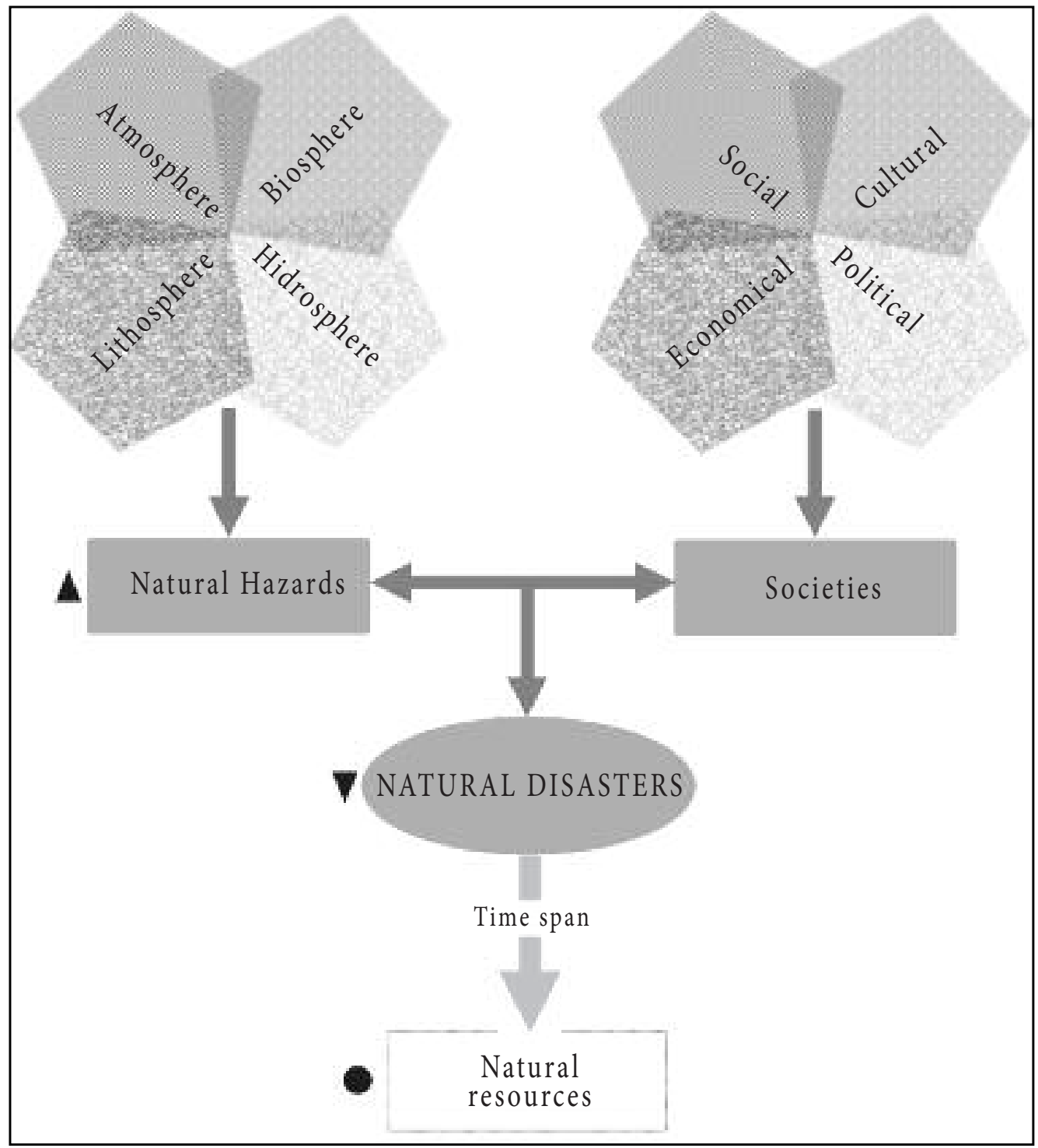

Figure 3: Sketch of the natural disaster system, with three levels at which the issue is treated in Serbian geography textbooks ( $\mathbf{\Delta}$ - hazard,

- resource; as in Table 3). 
regional scale had the human victims, large evacuations and extensive material damage, none of them has been mentioned in geography textbooks up to now - neither in the lessons on natural processes, nor in the lessons covering the regions of the affected areas. We can conclude that there is neither temporal nor spatial coordination between the Serbian natural disasters and Serbian geography textbooks. This fact leads to the substantial decrease of awareness and preparedness for a potential event.

\subsection{Teachers' opinion}

The analysis of teachers' opinions shows that a large number $(80 \%)$ of teachers believe their new knowledge could be applied in the classroom (Figure 4). A small number of teachers mostly agrees that they can apply the new knowledge (14\%), while a small number of them partially agree $(5 \%)$. Very few teachers believe that the theme of natural disasters would not be useful for their future work. Since the positive opinion on the applicability of new knowledge gained at the training program highly dominates, it can be interpreted as their will to teach about an attractive and important matter.

In the interview with the teachers, we discussed the reasons why some of them are anxious that the new knowledge on natural disasters is not sufficiently useful for their future work. The limitations they stated can be categorized into three groups:

- Formal limitations: extensive geography curriculum, but small number of classes per week, and no lessons on natural disasters. Solution of these problems requires a systematic approach, which means slow procedure. Therefore, the intermediate solution should be searched even prior to the modification of the curriculum (cf. Cummins 2010). Authors of textbooks should include innovations of this kind in textbooks, and publishers should support it. In Serbia, these changes occur slowly and there are rare examples of the positive outcomes of such initiatives (Milivojević and Ćalić 2012; Sitarica and Tadić 2010). Additional limitation in the implementation of these changes, as pointed by Grčić (2001), is the shaken position of geography in the system of sciences, which led to its suppression and destabilization in schools. This situation is caused by inaccordance between the curricula and pupils' perception, by excessive descriptive contents, by gaps in education and training of geography teachers, and the gap between university professors and teachers at schools (»university geography« vs. »school geography«) (Grčić 2001). Therefore, it is more difficult to impose the importance of geography as a science that teaches practical things in life.

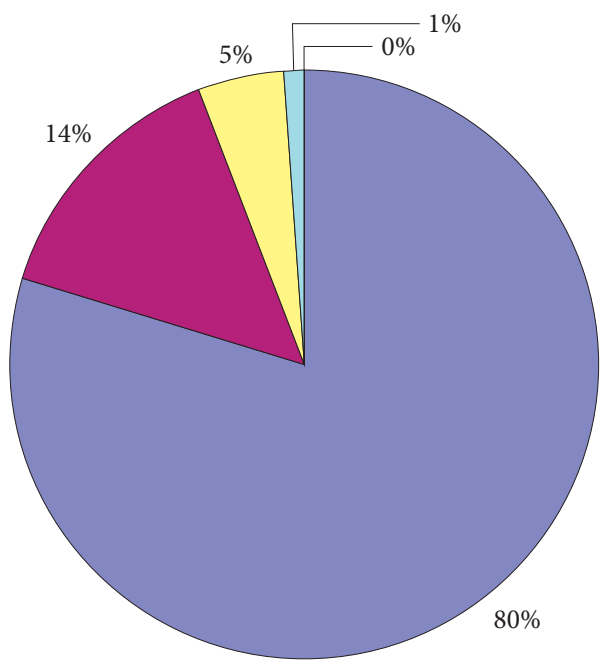

Program is applicable in practice, in schools

$\square$ Completely Agree
Mostly Agree
$\square$ Partially Agree
$\square$ Mostly Disagree
Completely Disagree

Figure 4: Applicability of additional knowledge about natural hazards in geography teaching, based on poll survey results (361 teachers). 
- Pupils' motivation: the degree of their interest to learn is often reported to be low (correlation with age, gender, discipline in class, the teacher, the methods used in class). This could be overcome by the fact that the issue of natural disasters is usually attractive to children and offers the possibilities for creative work (Mitchell et al. 2008; Reinfried 2004).

- Teachers' motivation - the degree of their interest to use their right to be innovative in teaching. Many teachers are strictly adhering to the curriculum, and as a reason for not introducing innovations in teaching they even state a fear of rigorous control inspections if they depart from the curriculum. This practice urgently needs a substantial change. On the other hand, there are also teachers who notice the lack of information in textbooks and atlases (e.g. Simović, 2007). According to Mitchell et al. (2008, 171), "... answering why we teach hazards is fairly straightforward, and more pressing question at present is this: how should we teach about hazards ...? «. Due to the marginal position of geography in education in Serbia (Grčić 2001) it is often difficult for some teachers to regain their lost self-confidence. The geographic scientific community should remind them that the future of geography lies in the "... interdisciplinary themes, (...) global processes, environmental problems, natural disasters, demographic changes, uneven regional development..." (Grčić 2001) and that they need just to redesign their knowledge (Annan 2006), understanding and accepting the new important role of geography. Generally speaking about the role of a teacher, Fridl et al (2009) note that their important role is to broaden their students' horizons by presenting and addressing a number of already existing and new topics differently.

\subsection{Children's selfreported behaviors, feelings and knowledge}

The poll survey about children's behaviors, feelings and knowledge on natural disasters, carried out in Kraljevo, showed some worrying results.

When asked about their reaction during the earthquake, $59 \%$ of the total group responded that they stayed in their homes not taking any measures of protection, while $24 \%$ said that they "just ran out." Only 15\% of participants reacted correctly, looking for an adequate shelter (under a table or within a door frame). The three mentioned answers are almost equally represented among pupils in primary and secondary schools. About $14 \%$ said that they reacted some other way (e.g. that they slept over mentioned event), which was a characteristic response for secondary schools (within this group, $73 \%$ are secondary schools students). More detailed analysis of primary schools student reactions during the Kraljevo earthquake was done by Panić et al. (2013).

When asked about their feelings at the time of the event, approximately $35 \%$ declared that they were frightened, whereas the feeling of complete helplessness expressed through "I was completely frightened and I did not know what to do, " was the answer of $20 \%$ of children. Among those who felt helpless, there were more girls (77\%) compared to boys (23\%). About $26 \%$ of the participants stayed calm during the earthquake, without any panic feeling, which is more common for the boys (62\%) than for the girls (38\%). About $18 \%$ did not choose any of the following categories (or they slept through the earthquake).

As for the question » Where did you learn how to behave during an earthquake to protect yourself from harm? «, 26\% said that they listened to their parents and the advice received from them. This response was more common for girls (67\%) and secondary school pupils (63\%). About $25 \%$ of respondents singled out the school as the place where they learned something about behavior during the earthquake, which was more common for secondary school pupils (55\%). The answer "mass media " was singled out by $21 \%$ of participants, and the internet by $9 \%$. About $5 \%$ of participants were using some other sources, while $12 \%$ said they never heard of such information.

Extremly large number of pupils (77\%) was not aware that they live in the area threatened by seismic hazard. A smaller group (23\%) are those who were aware of the earthquake occurrence possibility, $56 \%$ of which in primary and $44 \%$ in secondary schools.

When asked about the presence of earthquake-related issues in geography textbooks, $33 \%$ said they thought that the present contents were enough, while $67 \%$ thought that the existing material »should be expanded with the instructions on how to behave during an earthquake. "This attitude is equally characteristic for primary and secondary school pupils, with the exception that $100 \%$ of students in the final year of secondary school gave this response.

Analyzing the poll survey results in total, it is conspicuous that over $70 \%$ of children (regardless of age) did not respond adequately at the time of the earthquake. Since at that time (01:56 AM) children 
were mostly in their homes, we can suspect that they largely relied on the advice and guidance of their parents. Thus, the results show that neither parents nor children reacted reasonably and correctly, due to the lack of basic knowledge and skills to cope with emergency situations. Taking this into account, it is not surprising that more than $50 \%$ were extremely frightened or they panicked.

As the earthquake prevention and protection measures are not developed in Serbia, and are not included in geography curriculum or textbooks, the poll showed that the parents are the most important source of information for children.

However, in the days following the earthquake, a great number of aftershocks occurred. In this period, the additional lessons dedicated to earthquakes were organized in Kraljevo schools (regardless of geography classes). There were also a lot of information spread through the media, and individuals searched for information themselves on the Internet. Therefore, the pupils realized that their previous knowledge was highly insufficient, which made them believe that it is necessary to expand the existing curriculum and include mentioned topics to the geography textbooks, together with the practical training. Apart from the lack of general information, there is also a considerable lack of the knowledge about the local environment. A dramatically large number of children were unaware that their hometown and its wider area are facing a relatively high seismic hazard.

\section{Conclusion}

In the process of prevention of natural disasters, it is important to strengthen the awareness of teachers and children they are a very important link in the transmission of information. One of the basic principles of the Hyogo Framework is a better exchange and access to information, which is very successfully enforced through the International Decade for Natural Disaster Reduction (IDNDR) 1990-2009, and is still carried out through the Building the Resilience of Nations and Communities to Disaster 2005-2015. As a good information exchange is an important condition for preparedness and readiness for action in the event of natural disasters, all the links in information transmission have an equal importance. The example in Fig. 5 shows the geographers (experts, teachers) and pupils as the important links in the process of information exchange.

Following the Chain of information exchange, children should have an equal role as adults. Considering our poll survey results they are aware that they do not want to be victims, but active participants (as already described in numerous references, e.g. Clerveaux and Spence 2009; Chen et al. 2013). The efficiency of such approach was comfirmed by the positive experience of school-based earthquake education in Iran (Parsizadeh and Ghafory-Ashtiany 2010).

In Serbia, presently we only have a partial hazard education, but still not a proper risk education. The coverage of hazards is systematic, while the coverage of risk is random and poorly represented. General legal capacities for the inclusion of risk education (which would be an upgrade of the present hazard education) do exist, but presently the lower range legislation (Regulations on Curricula) lags behind and fails to follow the recommendations of the international conventions and national laws. Regardless of the present flaws in the curricula, the formal (compulsory) education and geography teaching are the best framework for risk education. The possible solutions do require the changes of curricula, but before the new regulations are enacted, the teachers' interventions in the teaching process must compensate the present limitations.

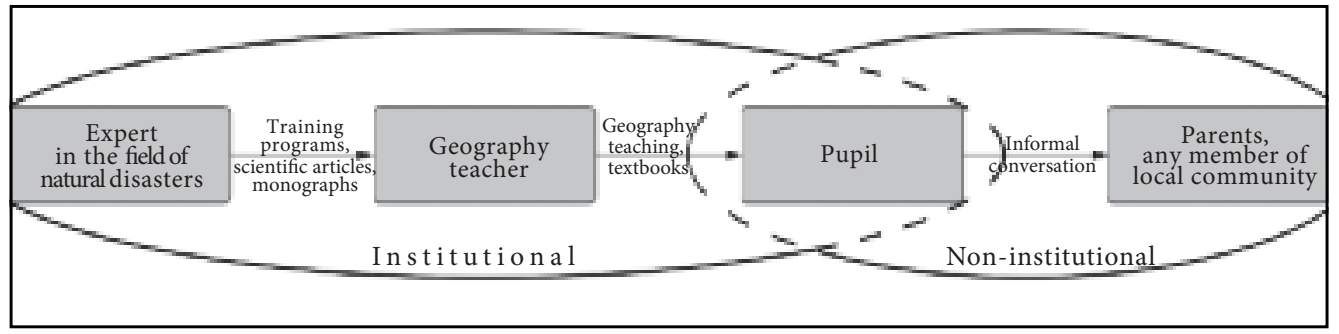

Figure 5: The chain of information exchange in the education process. 


\section{Acknowledgement}

The paper is a result of the project funded by Ministry of Education, Science and Technological Development, Republic of Serbia (project no. 47007). We are grateful to all teachers and pupils from Kraljevo schools who participated in the pool survey.

\section{References}

Agenda 21. Internet: http://www.un.org/esa/sustdev/documents/english/Agenda21.pdf (27.7.2012)

Alcántara-Ayala, I. 2002: Geomorphology, natural hazards, vulnerability and prevention of natural disasters in developing countries. Geomorphology 47-2. DOI: http://dx.doi.org/10.1016/S0169-555X(02)00083-1

Annan, K. 2006: Funkcija geografije po mišljenju Ujedinjenih Nacija. Globus 31.

Chen, C. Y., Yu, K. H., Chen, M. Y. 2012. Planning of professional teacher-training program for disaster prevention education and executing efficiency evaluation. Disaster prevention and management 21-5. DOI: http://dx.doi.org/10.1108/09653561211278734

Clerveaux, V., Spence, B. 2009: The communication of disaster information and knowledge to children using game technique: The disaster awareness game. International journal of environmental research 3-2.

Cross, J. A. 2009: Teaching hazards by geographers: A decade of change. Environmental Hazards 8. DOI: http://dx.doi.org/10.3763/ehaz.2009.0002

Cummnis, M. 2010: Eleven Years On: A case study of geography practices and perspectives within an Irish primary dchool. Internet: http://www.teachingcouncil.ie/_fileupload/Research/Bursary\%20Summaries/ MCummins_WEB.pdf (13.8.2012).

Đurić, V. 2011: Geografija za II razred gimnazije. Beograd.

Finnis, K. K., Johnston, D. M., Ronan, K. R., White, J.D. 2010: Hazard perceptions and preparedness of Taranaki youth. Disaster prevention and management 19-2. DOI: http://dx.doi.org/10.1108/09653561011037986

Golledge, R. G. 2002: The nature of geographic knowledge. Annals of the Association of American geographers 92-1. DOI: http://dx.doi.org/10.1111/1467-8306.00276

Grčić, M. 2001: Teorijsko-metodološki problemi geografije. Globus 26. Beograd.

Gritzner, C. F. 2004: The geographic »mental map«: Can »anyone« (really) teach geography? Journal of geography 103-1. DOI: http://dx.doi.org/10.1080/00221340408978571

Gulay, H. 2010: An earthquake education program with parent participation for preschool children. Educational research and review 5-10.

Fridl, J., Urbanc, M., Pipan, P. 2009: The importance of teachers' perception of space in education. Acta geographica Slovenica, 49-2. DOI: http://dx.doi.org/10.3986/AGS49205

Hyogo Framework for Action 2005-2015: Building the resilience of nations and communities to disasters: 2005.

Internet: http://www.unisdr.org/files/1037_hyogoframeworkforactionenglish.pdf (27.7.2012).

Izadkhah, Y. O., Hosseini, M. 2005: Towards resilient communities in developing countries through education of children for disaster preparedness. International Journal of Emergency Management 2-3, Geneva. DOI: http://dx.doi.org/10.1504/IJEM.2005.007355

Jakovljević, J., Birovljev, N. 2009: Moja planeta 7. Beograd

Johnston, D., Tarrant, R., Tipler, K., Coomer, M., Pedersen, S., Garside, R. 2011: Preparing schools for future earthquakes in New Zealand: lessons form an evaluation of a Wellington school exercise. The Australian Journal of Emergency Management 26-1.

Komac, B., Ciglič, R., Erhartič, B., Gašperič, P., Kozina, J., Orožen Adamič, M., Pavšek, M., Pipan, P., Volk, M., Zorn, M. 2010: Risk Education and Natural Hazards. CapHaz-Net WP6 Report. Anton-Melik geographical institute of the Scientific research centre of the Slovenian academy of sciences and arts. Ljubljana. Internet: http://caphaz-net.org/outcomes-results/CapHaz-Net_WP6_Risk-Education (25.8.2012).

Komac, B., Zorn, M., Ciglič, R. 2011: Izobraževanje o naravnih nesrečah v Evropi. Ljubljana. Internet: http://zalozba.zrc-sazu.si/414

Kuhlicke, C., Steinführer, A., Begg, C., Bianchizza C., Bründl, M., Buchecker, M., De Marchi, B., Di Masso Tarditti M., Höppner, C., Komac, B., Lemkow, L., Luther, J., McCarthy, S., Pellizzoni, L., Renn, O., Scolobig, 
A., Supramaniam, M., Tapsell, S., Wachinger, G., Walker, G., Whittle, R., Zorn, M., Faulkner, H. 2011: Perspectives on social capacity building for natural hazards: outlining an emerging field of research and practice in Europe. Environmental science \& policy 14. DOI: http://dx.doi.org/10.1016/j.envsci.2011.05.001

Milivojević, M., Ćalić, J. 2012: Geografija 5, za 5. razred osnovne škole. Beograd.

Mitchell, J. T., Borden, K. A., Schmidtlein, M. C. 2008: Teaching Hazards Geography and Geographic Information Systems: A Middle School Level Experience. International research in geographical and environmental education 17-2. DOI: http://dx.doi.org/10.1080/10382040802148679

Mitchell J. T. 2009: Hazards education and academic standards in the Southeast United States, International Research in Geographical and Environmental Education 18-2. Colchester. DOI: http://dx.doi.org/10.1080/ 10382040902861221

Panić, M., Kovačević - Majkić, J., Miljanović, D., Miletić, R. 2013: Importance of natural disaster education - Case study of the earthquake near the city of Kraljevo - first results. Journal of the Geographical Institute »Jovan Cvijić« SASA, 63(1). DOI: http://dx.doi.org/10.2298/IJGI121121001P

Parsizadeh, F., Ghafory-Ashtiany M. 2010: Iran public education and awareness program and its achievements. Disaster Prevention and Management 19-1. Bredford. DOI: http://dx.doi.org/10.1108/ 09653561011022126

Peek, L. 2008: Children and Disasters: Understanding Vulnerability, Developing Capacities, and Promoting Resilience - An Introduction Children. Youth, and Environments 18-1.

Reinfried, S. 2004: Do Curriculum Reforms Affect Classroom Teaching in Geography? The Case Study of Switzerland. International Research in Geographical and Environmental Education 13-3. DOI: http://dx.doi.org/10.1080/10382040408668518

Ronan, K. R., Crellin, K., Johnston, D. 2010: Correlates of hazards education for youth: a replication study. Natural Hazards 53. DOI: http://dx.doi.org/10.1007/s11069-009-9444-6

Ronan, K. R., Crellin, K., Johnston, D. M. 2012: Community readiness for a new tsunami warning system: quasi-experimental and benchmarking evaluation of a school education component. Natural Hazards 61. DOI: http://dx.doi.org/10.1007/s11069-011-0070-8

Senegačnik, J. 2010: The extent and content of the presentation of the geography of Europe in school textbooks in European countries. Acta geographica Slovenica 50-1. DOI: http://dx.doi.org/10.3986/AGS50104

Singh, R.B 2007: Current Curriculum Initiatives and Perspectives in Education for Natural Disaster Reduction in India. International Perspectives on Natural Disasters: Occurence, Mitigation, and Consequences. Dordrecht.

Simović, Z. Ž. 2007: Primena geografskih atlasa i karata u nastavi geografije (Tačnost sadržaja na kartama kao jedan od uslova pravilnog formiranja geografskog mišljenja kod učenika). Collection of papers 57. Geographical Institute »Jovan Cvijic « Serbian Academy of Sciences and Arts. Belgrade. Internet: http://www.gi.sanu.ac.rs/rs/izdanja/zbornik/pdf/057/gijc_zr_57_054_z_simovic_srp_eng.pdf (4.9.2012).

Sitarica, R., Tadić, M. 2010: Geografija za 5. razred osnovne škole. Beograd.

Statistical Office of the Republic of Serbia 2012: Pupils of primary school in the Republic of Serbia Beginning of 2011/2012. Belgrade. Internet: http://webrzs.stat.gov.rs/WebSite/Public/ReportResultView.aspx?rptKey=ind (5.8.2012).

Stoltman, J. P. 2006: Turning points in geographic education. Geographical Education in a Changing World: Past Experience, Current Trends and Future Challenges. Dordrecht.

The National Strategy on Protection and Rescue in Emergency Situations: 2011. National Assembly of the Republic of Serbia. Belgrade.

UN Decade of Education for Sustainable Development 2005-2014. Internet: http://www.desd.org (21.8.2012).

UNICEF and UNISDR 2011: Children and disasters: building resilience through education. Internet: http://www.unisdr.org/files/24583_childrenanddisastersbuildingresilie.pdf (27.7.2012).

UNISDR 2007: Towards a culture of prevention: disaster risk reduction begins at school - good practices and lessons learned. Geneva. Internet: http://www.unisdr.org/files/761_education-good-practices.pdf (25.7.2012)

UNISDR 2009: Terminology on Disaster Risk Reduction. http://www.unisdr.org/files/7817_UNISDRTerminologyEnglish.pdf (5.8.2012)

UNISDR World Campaign - disaster risk reduction begins at school 2006-2007 Internet: http://www.unisdr.org/ 2007/campaign/wdrc-2006-2007.htm (1.8.2012) 
UN World Disaster Reduction Campaign on Disaster Prevention, Education and Youth: 2000. Internet: http://www.unisdr.org/2000/campaign/pa-camp00-kit-eng.htm (8.8.2012)

Wisner, B., Blaikie, P., Cannon, T., Davis, I. 2004: At risk: natural hazards, people's vulnerability and disasters. London and New York.

Wisner, B. 2006: Let Our Children Teach Us!. A Review of the Role of Education and Knowledge in Disaster Risk Reduction. Internet// www.unisdr.org/knowlwdge-education (15.7.2012)

Zorn, M., Komac, B. 2011: Damage caused by natural disasters in Slovenia and globally between 1995 and 2010. Acta geographica Slovenica letnik 51-1. DOI: http://dx.doi.org/10.3986/AGS51101 